\title{
Correction: Weight Science: Evaluating the evidence for a paradigm shift
}

Linda Bacon ${ }^{1,3^{*}}$ and Lucy Aphramor ${ }^{1,2}$

\section{Correction}

\section{Erratum}

Since publication of this article [1], it has come to our attention that there is an error in the section discussing assumptions about obesity-related costs. Table 2 is correct, indicating that $36 \%$ of the population is misidentified when BMI is considered, but there is a typographical error in the text which reported it as $31 \%$.

\begin{abstract}
Author details
'University of California, Davis, and City College of San Francisco, Box S-80, City College of San Francisco, 50 Phelan Avenue, San Francisco, CA 94112, USA. ${ }^{2}$ Coventry University, Applied Research Centre in Health and Lifestyle Interventions, Priory Street, Coventry, CV1 1FB, UK. ${ }^{3}$ University Hospitals Coventry and Warwickshire NHS Trust, Cardiac Rehab, Cardiology Suite, 1st Floor, East Wing, Walsgrave Hospital, Clifford Bridge Road, Coventry CV2 2DX, UK.
\end{abstract}

Received: 17 June 2011 Accepted: 17 June 2011

Published: 17 June 2011

\section{Reference}

1. Bacon L, Aphramor L: Weight Science: Evaluating the evidence for a paradigm shift. Nutr J 2011, 10:9.

doi:10.1186/1475-2891-10-69

Cite this article as: Bacon and Aphramor: Correction: Weight Science: Evaluating the evidence for a paradigm shift. Nutrition Journal 2011 10:69.

* Correspondence: linda@lindabacon.org

${ }^{1}$ University of California, Davis, and City College of San Francisco, Box S-80, City College of San Francisco, 50 Phelan Avenue, San Francisco, CA 94112, USA

Full list of author information is available at the end of the article

Submit your next manuscript to BioMed Central and take full advantage of:

- Convenient online submission

- Thorough peer review

- No space constraints or color figure charges

- Immediate publication on acceptance

- Inclusion in PubMed, CAS, Scopus and Google Scholar

- Research which is freely available for redistribution

Submit your manuscript at www.biomedcentral.com/submit

\section{Biomed Central}

